OPEN ACCESS

Edited by:

Victoria Fernandez,

Polytechnic University of Madrid,

Spain

Reviewed by:

Roslyn Gleadow,

Monash University, Australia

Hongzhang Kang,

Shanghai Jiao Tong University,

China

*Correspondence:

Uri Yermiyahu

uri4@agri.gov.il

Or Sperlingr

orsp@agri.gov.il

Specialty section:

This article was submitted to

Plant Nutrition,

a section of the journal

Frontiers in Plant Science

Received: 16 April 2019

Accepted: 26 July 2019

Published: 11 September 2019

Citation:

Omondi JO, Lazarovitch N,

Rachmilevitch S, Yermiyahu U and Sperling O (2019) High Nitrogen Availability Limits Photosynthesis and Compromises Carbohydrate Allocation to Storage in Roots of

Manihot esculenta Crantz.

Front. Plant Sci. 10:1041.

doi: 10.3389/fp/s.2019.01041

\section{High Nitrogen Availability Limits Photosynthesis and Compromises Carbohydrate Allocation to Storage in Roots of Manihot esculenta Crantz}

\author{
John Okoth Omondi 1,2, Naftali Lazarovitch ${ }^{1}$, Shimon Rachmilevitch ${ }^{1}$, Uri Yermiyahu ${ }^{2 *}$, \\ and Or Sperling ${ }^{2 *}$
}

${ }^{1}$ French Associates Institute for Agriculture and Biotechnology of Drylands, Ben-Gurion University of the Negev, Midreshet Ben-Gurion, Israel, ${ }^{2}$ Gilat Research Center, Agricultural Research Organization, Gilat, Israel

Cassava (M. esculenta Crantz), feeding countless people and attracting markets worldwide, is a model for traditional crops that need physiology-based fertigation (fertilization through irrigation) standards in intensive cultivation. Hence, we studied the effects of 10 to $200 \mathrm{mg}$ $\mathrm{L}^{-1}$ nitrogen $(\mathrm{N})$ fertigation on growth and yields of cassava and targeted alterations in their photosynthetic, transpiration, and carbohydrate management. We found that increasing irrigation $\mathrm{N}$ from 10 to $70 \mathrm{mg} \mathrm{L}^{-1}$ increased cassava's photosynthesis and transpiration but supported only the canopy's growth. At $100 \mathrm{mg} \mathrm{N} \mathrm{L}^{-1}$ cassava reached a threshold of sugar in leaves $\left(\sim 47 \mathrm{mg} \mathrm{g}^{-1}\right)$, began to accumulate starch and supported higher yields. Yet, at $200 \mathrm{mg} \mathrm{N} \mathrm{L}^{-1}$, the canopy became too demanding and plants had to restrain transpiration, reduce photosynthesis, decrease carbohydrates, and finally lower yields. We concluded that the phases of cassava response to nitrogen are: 1) growth that does not support yields at low N, 2) productive $N$ application, and 3) excessive use of $N$. Yet traditional leaf mineral analyses fail to exhibit these responses, and therefore we propose a simple and inexpensive carbohydrate measurement to guide a precise use of $\mathrm{N}$.

Keywords: root-crops, nitrogen, fertigation, carbohydrates, physiological indicators

\section{INTRODUCTION}

With increased pricing of fertilizers and rising environmental concerns, the effectivity of nutrient application has to be studied thoroughly for every new crop, condition, and farming practice. It is especially critical in arid and semi-arid environments, where the shift to intensive fertilization through irrigation (i.e., fertigation) alters the nutrient uptake and use and requires specific considerations (He et al., 2015). Of all the macro-elements, modern farming relies heavily on nitrogen (N), which, despite becoming increasingly costly, cannot be substituted by farmers. Nitrogen-deficient plants halt leaf elongation (Marschner and Marschner, 2012), inhibit photosynthesis (Gregoriou et al., 2007), reduce chloroplast size (Li et al., 2013), and minimize overall growth. Yet, if N levels increase and it is no longer a limiting factor in physiological processes, its effectivity must be reassessed. In fact, the majority of applied $\mathrm{N}$ in crop systems often does not transform to increased yield (Lassaletta et al., 2014) due to numerous parameters that affect its effectivity, e.g. crop species and variety, the $\mathrm{N}$ form (nitrate or ammonium), soil type, water availability, and application method (El-Sharkawy et al., 1998; Ospina et al., 2014). Thus, $\mathrm{N}$ should be studied within the conditions and limitations of 
the entire farming environment to ensure its application supports yield and profits.

Cassava (Manihot esculenta Crantz) cultivation is expanding, and its intensive cultivation needs to be studied thoroughly. This South American native (Nassar, 2007) is the third largest source of carbohydrates in the tropics and the sixth most important crop worldwide (Lebot, 2008). It is not only a food staple to over 500 million people, but an important constituent in commercial animal feed, paper or textile fibers, and starch for pharmaceutical industries (Balagopalan, 2002; Tonukari et al., 2015). Due to water scarcity, cassava farms are shifting to drip irrigation, and production could increase further by better soluble nutrients application (Susan John et al., 2007; Fermont et al., 2009; Byju et al., 2012). So far, we know that $\mathrm{N}$ fertilization increases $\mathrm{N}$ concentration in the leaf blade (Nguyen et al., 2002), leaf area index (Sangakkara and Wijesinghe, 2014), photosynthetic rate (Cruz et al., 2003b), plant height, number of leaves, stem diameter, and the number of roots (Uwah et al., 2013) of cassava. However, the effect on root yield is arguable, as earlier studies suggested that $\mathrm{N}$ application induces cassava shoot growth at the expense of storage root formation (Cenpukdee and Fukai, 1991) and starch content (Cruz et al., 2003a). More recently, Nguyen et al. (2002) observed a yield decline at $160 \mathrm{~kg} \mathrm{~N}^{-1}$ for the first year of application, while Kaweewong et al. (2013) reported optimal root yields at $\mathrm{N}$ applications as high as $250 \mathrm{~kg}$ $\mathrm{N} \mathrm{ha}^{-1}$. Conversely, Uwah et al. (2013) showed no yield response to an increase from 80 to $120 \mathrm{~kg} \mathrm{~N} \mathrm{ha}^{-1}$ whatsoever. These studies demonstrate that cassava responds to $\mathrm{N}$ fertilization and that yields can improve but emphasize that physiological bases for efficient $\mathrm{N}$ use are still obscure.

Matching $\mathrm{N}$ application to crops' requirements calls for studying its specific physiological effects. As $\mathrm{N}$ constitutes a part of the carbon sinks (e.g. amino acids and proteins), it has a positive effect on photosynthesis and transpiration (Leuning et al., 1995; Bar-Tal et al., 2001). Nitrogen is critical initially at the leaf level, where it improves radiation-use efficiency and promotes photosynthetic productivity (Sinclair and Horie, 1989). Yet high levels of photosynthates, without adequate transport, can signal that the capacity for non-structural carbohydrates (NSC) has reached its maximum, and down-regulate photosynthesis (Goldschmidt and Huber, 1992). Moreover, N tends to promote vegetative growth (Kang et al., 2004), increase a plant's root-toshoot ratio (Grechi et al., 2007), and might exhaust the roots' water delivery capacity. Indeed, it is low $\mathrm{N}$ that promotes root growth (critical for root-crops as cassava) and supports high transpiration demands (Marschner and Marschner, 2012). In a water-limiting environment, high $\mathrm{N}$ levels could restrain water losses and the corresponding $\mathrm{CO}_{2}$ sequestration, and force plants to utilize their residual photosynthates in the canopy at the expense of roots and reproduction. This implies that besides growth, water, and nutrient uptake, NSC levels could indicate whether the $\mathrm{N}$ application is effective.

Consequently, we studied $\mathrm{N}$ application in fertigated cassava and the physiological implications of high $\mathrm{N}$ availability. We postulated that if $\mathrm{N}$ supports shoots over root development then root-crops (e.g. Cassava) are prone to over-fertilization. Our objectives were therefore to 1 ) define physiological responses in
$\mathrm{N}$ fertigation levels ranging from 10 to $200 \mathrm{mg} \mathrm{L}^{-1}$ and 2) determine a physiological indicator to the effectivity of $\mathrm{N}$ application on cassava yields. We used inert perlite, which does not buffer the minerals, and studied the presence and form of $\mathrm{N}$ in leaves. We also targeted the processes that drive the starch accumulation in roots of cassava, i.e., photosynthesis and carbohydrate management to form new applied indexes.

\section{MATERIALS AND METHODS}

\section{Setup}

We experimented with 30 potted cassava plants (Manihot esculenta Crantz cv. Israeli) in a greenhouse at Gilat Research Center, Israel $\left(31^{\circ} 20^{\prime} \mathrm{N}\right.$ and $\left.34^{\circ} 39^{\prime} \mathrm{E}\right)$ during the summer of 2014 (Exp. 1). The average humidity in the greenhouse was $80 \%$, radiation $136 \mathrm{~W} \mathrm{~m}^{-2}$, and temperature $23^{\circ} \mathrm{C}$. Plants were trimmed in mid-season (100 days after growth) and therefore we could not report on total biomass in Exp. 1 (we did include the rest of the growth parameters from Exp. 1 in the final analysis). Hence, we repeated the experiment in the summer of 2015 (Exp. 2), included final canopy biomass, and reinforced our findings. In both experiments, cassava cuttings $(20 \mathrm{~cm}$ long) were planted with 6 nodes in 2-L pots (a single cutting per pot) filled with $6 \mathrm{~mm}$ perlite granules with high porosity, high hydraulic conductivity, and minimum interaction with nutrients (Erel et al., 2015). For the first 28 days, plants were hand-irrigated every $48 \mathrm{~h}$ with $500 \mathrm{ml}$ nutrient solution (100 mg N L-1, $10 \mathrm{mg} \mathrm{P} \mathrm{L}^{-1}$, $100 \mathrm{mg} \mathrm{K} \mathrm{L}^{-1}, 60 \mathrm{mg} \mathrm{Ca} \mathrm{L}^{-1}, 30 \mathrm{mg} \mathrm{Mg} \mathrm{L}^{-1}$, and microelements). Then, plants (now having $\sim 5$ leaves) were transplanted in $60-\mathrm{L}$ pots filled with perlite, and the $\mathrm{N}$ concentration in the fertigation changed to either $10,40,70,100,150$, or $200 \mathrm{mg} \mathrm{N} \mathrm{L}^{-1}(0.7,2.9$, $5,7.1,10.7,14.3 \mathrm{mM} \mathrm{N}$, respectively). There were 5 plants per treatment in a complete randomized design, the concentrations of microelements in the irrigation did not change, and the irrigation quantity was fixed periodically (by collecting and weighing drainage for $24 \mathrm{~h}$ ) to ensure a 0.3 leaching fraction.

\section{N Solution Preparation}

Stock solutions for the experiment were made of dissolved $\mathrm{NH}_{4} \mathrm{NO}_{3}, \mathrm{NH}_{4} \mathrm{H}_{2} \mathrm{PO}_{4}, \mathrm{KH}_{2} \mathrm{PO}_{4}, \mathrm{~K}_{2} \mathrm{SO}_{4}, \mathrm{KNO}_{3}, \mathrm{NaNO}_{3}$, and $\mathrm{MgCl}_{2}$ in tap water [electrical conductivity (EC) of $0.3-0.4 \mathrm{dS} \mathrm{m}^{-1}$ ]. Then, stock solutions were diluted by 200 times in 1,200-L tanks to final fertigation solutions. These final solutions were also supplemented with $\mathrm{Mg}, \mathrm{Ca}$ and microelements $\left(60 \mathrm{mg} \mathrm{Ca} \mathrm{L}^{-1}, 30 \mathrm{mg} \mathrm{Mg} \mathrm{L}^{-1}\right.$, $8,0 \mathrm{mg} \mathrm{Fe} \mathrm{L}{ }^{-1}, 4.0 \mathrm{mg} \mathrm{Mn} \mathrm{L}{ }^{-1}, 2.0 \mathrm{mg} \mathrm{Zn} \mathrm{L}^{-1}, 0.4 \mathrm{mg} \mathrm{B} \mathrm{L}^{-1}$, $0.3 \mathrm{mg} \mathrm{Cu} \mathrm{L}^{-1}$, and $0.22 \mathrm{mg} \mathrm{Mo} \mathrm{L}^{-1}$ ) and the proportions of $\mathrm{NO}_{3}{ }^{-}$to $\mathrm{NH}_{4}{ }^{+}$were always fixed at 9:1. The stock and final solutions were regularly sampled and analyzed for $\mathrm{NO}_{3}{ }^{-}, \mathrm{NH}_{4}{ }^{+}, \mathrm{P}$, and $\mathrm{K}$ to verify if they were within $5 \%$ of the anticipated levels, while the $\mathrm{pH}$ and the EC in the final solution were checked weekly and ranged at 6.9 \pm 0.3 and $0.95 \pm 0.1 \mathrm{dS} \mathrm{m}^{-1}$, respectively.

\section{Measurements and Harvest}

The youngest fully expanded leaves (diagnostic leaf) were sampled at 29,51 , and 88 days of treatment (DOT) and separated to blade 
and petiole for mineral analysis. Photosynthesis $\left(A_{n}, L I-6400\right.$, Li-Cor Inc., Lincoln, NE, USA) and stomatal conductance $(g$, LI-6400) of matured, sun-exposed leaves were measured after 91 days of growth in three plants per treatment between 10:00 and 13:00. The reference $\mathrm{CO}_{2}$ in the LI-6400 was set to 400 ppm, light to $1,000 \mu \mathrm{mol} \mathrm{m} \mathrm{m}^{-2} \mathrm{~s}^{-1}$, and temperature and humidity levels were ambient $\left(\sim 30^{\circ} \mathrm{C}\right.$ and $40 \% \mathrm{RH}$ in the greenhouse). All the plants were harvested after 190 days of growth, divided into tuberous roots, stem, and leaves. The total fresh weight was recorded and all the samples were oven-dried at $70^{\circ} \mathrm{C}$ for $48 \mathrm{~h}$, and they were then re-weighed to ascertain their water content and dry mass (DM). Finally, leaves of 18 plants (3 replicates per treatment) were stored for subsequent lab carbohydrate analysis.

\section{Laboratory Analysis}

Dried leaf samples were ground in a stainless-steel coffee mill to $0.5 \mathrm{~mm}$ particle size and measured for total $\mathrm{N}$ in the leaf blade by digestion in sulfuric acid and peroxide (Snell and Snell, 1949). The $\mathrm{NO}_{3}{ }^{-}$portion was also determined in the leaf petiole (Yermiyahu et al., 2017) by weighing $100 \mathrm{mg}$ of dry powder, mixing it in $10 \mathrm{ml} \mathrm{DI}$ for $30 \mathrm{~min}$, filtering it through paper (Whatman 42), and detecting the concentration by an automated photometric analyzer (Thermo Scientific Gallery Plus).

Non-structural carbohydrates (NSC) in leaves were extracted by an updated version of Leyva et al. (2008) from finely ground (MiniBeadbeater-96, Glen Mills Inc., NJ) tissues. A $25 \mathrm{mg}$ portion of the dry leaf sample was mixed with $550 \mu \mathrm{l} \mathrm{Na}$ acetate buffer (pH 5.8) and shaken for $15 \mathrm{~min}$ at $72^{\circ} \mathrm{C}$ in $1.5 \mathrm{ml}$ tubes. The insoluble tissue was precipitated in a centrifuge $(17,000 \mathrm{~g})$ and $50 \mu \mathrm{l}$ of the supernatant was collected for soluble carbohydrate (SC) analysis. The samples were then hydrolyzed for $20 \mathrm{~min}$ at $100^{\circ} \mathrm{C}$, cooled to room temperature, and incubated with $100 \mu \mathrm{l}$ amyloglucosidase and $100 \mu \mathrm{l} \alpha$-amylase for $4 \mathrm{~h}$ at $37^{\circ} \mathrm{C}$ (while shaking) to digest starch. The mixture was reprecipitated in the centrifuge $(17,000 \mathrm{~g})$ and another $50 \mu \mathrm{l}$ of supernatant was collected for the starch analysis.

To quantify carbohydrates, the $50 \mu$ supernatants (for both SC and starch) were diluted in $1 \mathrm{ml}$ of DI. Then $50 \mu \mathrm{l}$ of the solutions were mixed in a 96-well micro-plate with $150 \mu \mathrm{l}$ anthrone and $98 \%$ sulfuric acid $(0.1 \% \mathrm{w} / \mathrm{v})$. The plate was heated to $100^{\circ} \mathrm{C}$ for $10 \mathrm{~min}$ in a water bath, cooled to room temperature for another $10 \mathrm{~min}$, and the absorbance at $620 \mathrm{~nm}$ was measured in a plate reader (Multiskan GO, Thermo Scientific, Finland). The readings were compared to a linear regression of glucose standards $(0.01$, $0.03,0.1$, and $\left.0.3 \mathrm{~g} \mathrm{~L}^{-1}\right)$, and the equivalent SC concentration was computed. The original supernatant collection stood for SC concentrations in the samples, while the delta between the readings before and after the enzymatic reaction represented the starch levels.

\section{Statistics}

The variance of the results was tested by a one-way ANOVA, and the means were compared by LSD (95\% confidence) using the SAS software (SAS, 2002). Relations between transpiration and photosynthetic performance, and between dry root yield and leaf carbohydrates (soluble sugar and starch), were assessed by linear regression.

\section{RESULTS}

\section{Growth, Yield, and N Diagnosis}

Cassava plants doubled their shoot mass (from 330 to $760 \mathrm{~g} \mathrm{DM}$ plant $^{-1}$ ) as $\mathrm{N}$ irrigation levels increased from 10 to $70 \mathrm{mg} \mathrm{L}^{-1}$ (Figure 1A). However, shoots retained similar mass $(\sim 780 \mathrm{~g}$ plant $^{-1}$ ) at 70,100 , and $150 \mathrm{mg} \mathrm{N} \mathrm{L}^{-1}$. At $200 \mathrm{mg} \mathrm{N} \mathrm{L}^{-1}$ in irrigation, cassava plants induced shoot mass, to $850 \mathrm{~g} \mathrm{plant}^{-1}$ $(0.1>\mathrm{P}>0.05)$. Nitrogen did not have such a positive effect on cassava root between 10 and $100 \mathrm{~g} \mathrm{~N} \mathrm{~L}^{-1}$ in irrigation, as they maintained an average mass of $407 \mathrm{~g}$ in Exp. 1 and $440 \mathrm{~g}$ in Exp. 2 (despite an increase between 10 and $40 \mathrm{mg} \mathrm{N} \mathrm{L}^{-1}$ ). Roots induced mass at $150 \mathrm{~g} \mathrm{~N} \mathrm{~L}^{-1}$ and reached $\sim 600 \mathrm{~g} \mathrm{plant}^{-1}$ in both years. Yet most importantly, $200 \mathrm{mg} \mathrm{N} \mathrm{L}^{-1}$ in irrigation severely inhibited cassava root development and reduced mass significantly to $389 \mathrm{~g} \mathrm{plant}^{-1}$ and $352 \mathrm{~g} \mathrm{plant}^{-1}$ at Exp. 1 and Exp. 2, respectively.

Diagnostic leaves of cassava did not indicate such dramatic effects of $\mathrm{N}$ on cassava roots or canopy development (Figure 1B, detailed statistics at Table 1). In fact, the only differences appeared between the sampling dates (Table 1) as $\mathrm{N}$ concentrations in diagnostic leaves increased from $3.2 \%$ to $3.9 \%$, and $4.8 \%( \pm 0.2 \%)$ between the $29^{\text {th }}, 51^{\text {st }}$, and $88^{\text {th }}$ days of treatments. It is important to note that we always sampled young fully expanded leaves and these differences are not the net accumulation of $\mathrm{N}$ in individual leaves. Nitrate in the petiole, i.e., unfixed $\mathrm{N}$ deposited from sap, did respond to irrigation $\mathrm{N}$ and its concentrations gradually increased from $0.19 \%$ to $0.86 \%$ between 10 and $150 \mathrm{~g} \mathrm{~L}^{-1}$ at the $88^{\text {th }}$ day of treatment, and then decreased to $0.64 \%$ at $200 \mathrm{mg}$ $\mathrm{N} \mathrm{L}^{-1}$ (Figure 1C). At the $29^{\text {th }}$ and $51^{\text {st }}$ days of treatment nitrate concentrations likewise increased from $\sim 0.13 \%$ to $0.5 \%$ and $0.7 \%$ ( $29^{\text {th }}$ and $51^{\text {st }}$, respectively), and decreased to $\sim 0.47 \%$ with the $200 \mathrm{mg} \mathrm{N} \mathrm{L}^{-1}$ treatment.

\section{Photosynthetic Attributes}

Midday photosynthesis increased from 20 to $32 \mu \mathrm{mol} \mathrm{m} \mathrm{m}^{-2} \mathrm{~s}^{-1}$ between 10 and $70 \mathrm{mg} \mathrm{N} \mathrm{L}^{-1}$ in irrigation (Figure 2A). Then it increased gradually (though not significantly different) to $35 \mu \mathrm{mol}$ $\mathrm{m}^{-2} \mathrm{~s}^{-1}$ at $150 \mathrm{mg} \mathrm{N} \mathrm{L}^{-1}$, and finally dropped sharply to $26 \mu \mathrm{mol}$ $\mathrm{m}^{-2} \mathrm{~s}^{-1}$ at $200 \mathrm{mg} \mathrm{N} \mathrm{L}^{-1}$. Stomatal conductance also increased due to $\mathrm{N}$ application, almost linearly between 10 and $150 \mathrm{mg} \mathrm{L}^{-1}(240$ to $\left.350 \mathrm{mmol} \mathrm{m}^{-2} \mathrm{~s}^{-1}\right)$, followed by a minor drop to $330 \mathrm{mmol} \mathrm{m}^{-2} \mathrm{~s}^{-1}$ at $200 \mathrm{mg} \mathrm{N} \mathrm{L}^{-1}$. The photosynthetic rate was best correlated to the total daily transpiration (Figure 2B). It increased linearly from $\sim 20 \mu \mathrm{mol} \mathrm{m}{ }^{-2} \mathrm{~s}^{-1}$ to $\sim 35 \mu \mathrm{mol} \mathrm{m}{ }^{-2} \mathrm{~s}^{-1}$, as transpiration augmented from $1,150 \mathrm{~g} \mathrm{day}^{-1}$ to $2,050 \mathrm{~g} \mathrm{day}^{-1}$ (over $2 \mathrm{~L}$ a day per plant). Yet the $\mathrm{N}$ treatments did not dictate this correlation, as plants irrigated with $200 \mathrm{mg} \mathrm{N} \mathrm{L}^{-1}$ transpired like plants irrigated with $40 \mathrm{mg} \mathrm{L}^{-1}$, and even photosynthesized slightly less $\left(26 \mu \mathrm{mol} \mathrm{m} \mathrm{m}^{-2} \mathrm{~s}^{-1}\right.$ vs. $27.5 \mu \mathrm{mol} \mathrm{m}^{-2} \mathrm{~s}^{-1}$ ), i.e., well below the 70,100 , and $150 \mathrm{mg} \mathrm{N} \mathrm{L}^{-1}$ treated plants. 

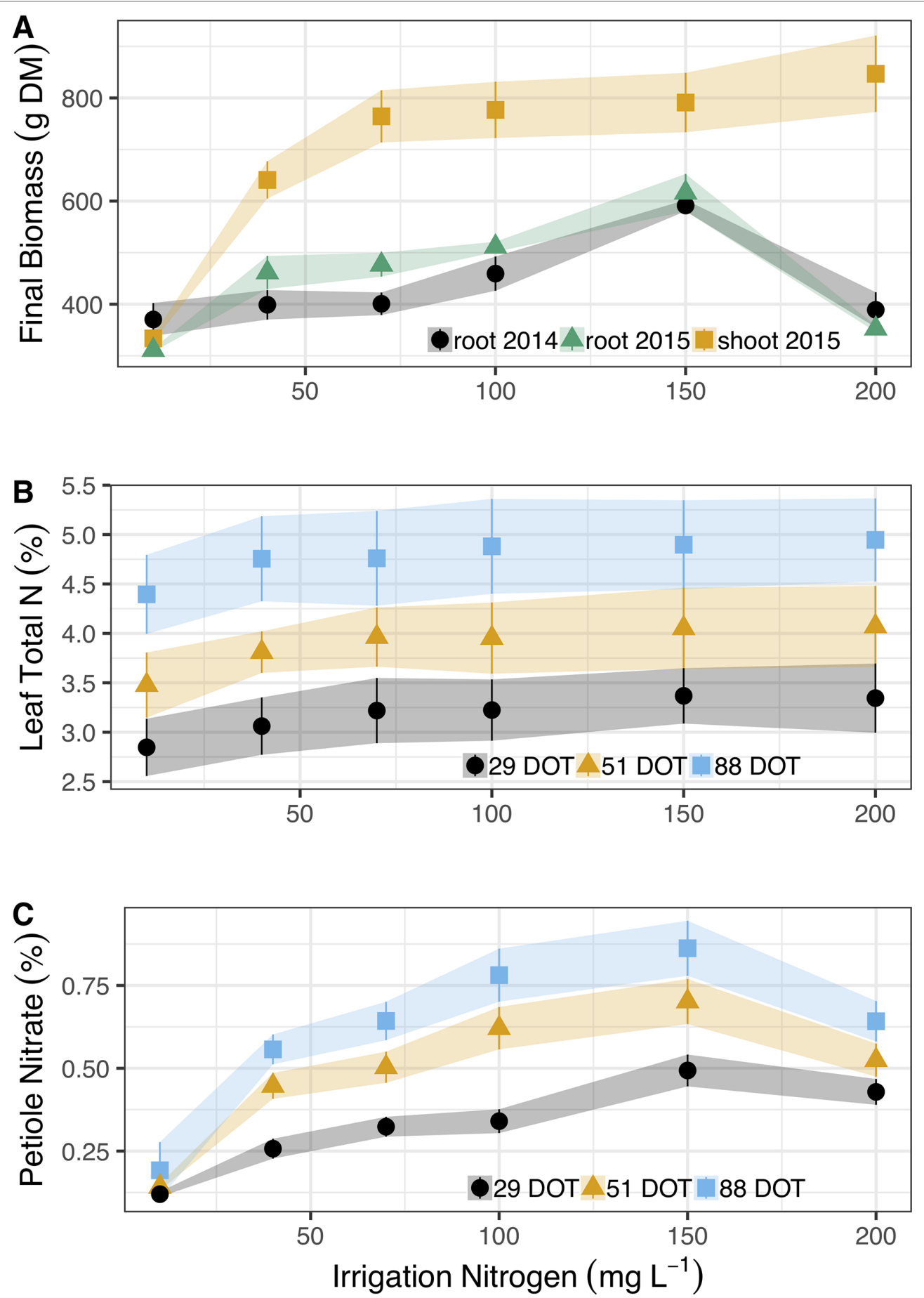

FIGURE 1 | Irrigation N concentrations' (10, 40, 70, 100, 150, and $200 \mathrm{mg} \mathrm{L}^{-1}$ ) effect on (A) Dry shoot mass accumulation (g) in 2015 (yellow squares) and dry root yields in 2014 (black circles) and 2015 (green triangles). (B) Total N concentrations (\%) in the leaf blade after 29 (black circles), 51 (yellow triangles), and 88 (blues squares) days of treatment (DOT). (C) Corresponding nitrate concentrations (\%) in the leaf petioles of cassava. Shapes represent means (five biological replicates) whereas vertical bars and ribbons mark SE.

\section{Non-Structural Carbohydrates}

Cassava leaves induced SC levels from 28 to $46 \mathrm{mg} \mathrm{g}^{-1} \mathrm{DM}$ as irrigation $\mathrm{N}$ increased from 10 to $70 \mathrm{mg} \mathrm{L}^{-1}$ (Figure 3A). At $150 \mathrm{mg} \mathrm{N} \mathrm{L}^{-1}$, SC levels increased again, slightly, to $48 \mathrm{mg} \mathrm{g}^{-1}$, but dropped to 43 at $200 \mathrm{mg} \mathrm{N} \mathrm{L}^{-1}$. Starch followed the same trend in a bigger scale as it increased from $51 \mathrm{mg} \mathrm{g}^{-1}\left(10 \mathrm{mg} \mathrm{L}^{-1}\right)$ to $\sim 72 \mathrm{mg} \mathrm{g}^{-1}$ (for 70,100 , and $150 \mathrm{mg} \mathrm{N} \mathrm{L}^{-1}$ treated plants) and then reduced to $65 \mathrm{mg} \mathrm{g}^{-1}$ at $200 \mathrm{mg} \mathrm{N} \mathrm{L}^{-1}$ irrigation. Strikingly, 
TABLE 1 | One-way ANOVA for Total $\mathrm{N}(\%)$ and Nitrate $\left(\mathrm{NO}_{3}^{-}, \%\right)$ in leaves of cassava after 29, 51, and 88 days of irrigation (days of treatment - DOT) with 10, 40, 70 , 100,150 , and $200 \mathrm{mg} \mathrm{N} \mathrm{L}^{-1}$.

\begin{tabular}{|c|c|c|c|c|c|c|}
\hline $\begin{array}{l}\text { Fertigation (mg } \\
\mathrm{N} \mathrm{L}^{-1} \text { ) }\end{array}$ & \multicolumn{2}{|c|}{ DOT 29} & \multicolumn{2}{|c|}{ DOT 51} & \multicolumn{2}{|c|}{ DOT 88} \\
\hline 10 & $2.85 \mathrm{~A}$ & $0.12 \mathrm{D}$ & $3.48 \mathrm{~A}$ & $0.14 \mathrm{C}$ & $4.4 \mathrm{~A}$ & $0.192 \mathrm{C}$ \\
\hline 70 & $3.22 \mathrm{~A}$ & $0.32 \mathrm{~B}$ & $3.96 \mathrm{~A}$ & $0.50 \mathrm{AB}$ & $4.76 \mathrm{~A}$ & $0.64 \mathrm{AB}$ \\
\hline 100 & $3.22 \mathrm{~A}$ & $0.34 \mathrm{~B}$ & $3.95 \mathrm{~A}$ & 0.62 A & $4.88 \mathrm{~A}$ & $0.78 \mathrm{~A}$ \\
\hline 150 & $3.37 \mathrm{~A}$ & $0.49 \mathrm{~A}$ & $4.05 \mathrm{~A}$ & $0.7 \mathrm{~A}$ & $4.9 \mathrm{~A}$ & $0.86 \mathrm{~A}$ \\
\hline
\end{tabular}

Capital letters denote comparison of means by Tukey-LSD (5 biological replicates, $P<0.05$ ) in total $\mathrm{N}$ or $\mathrm{NO}_{3}{ }^{-}$levels at DOT 29,51 , or 88 independently.
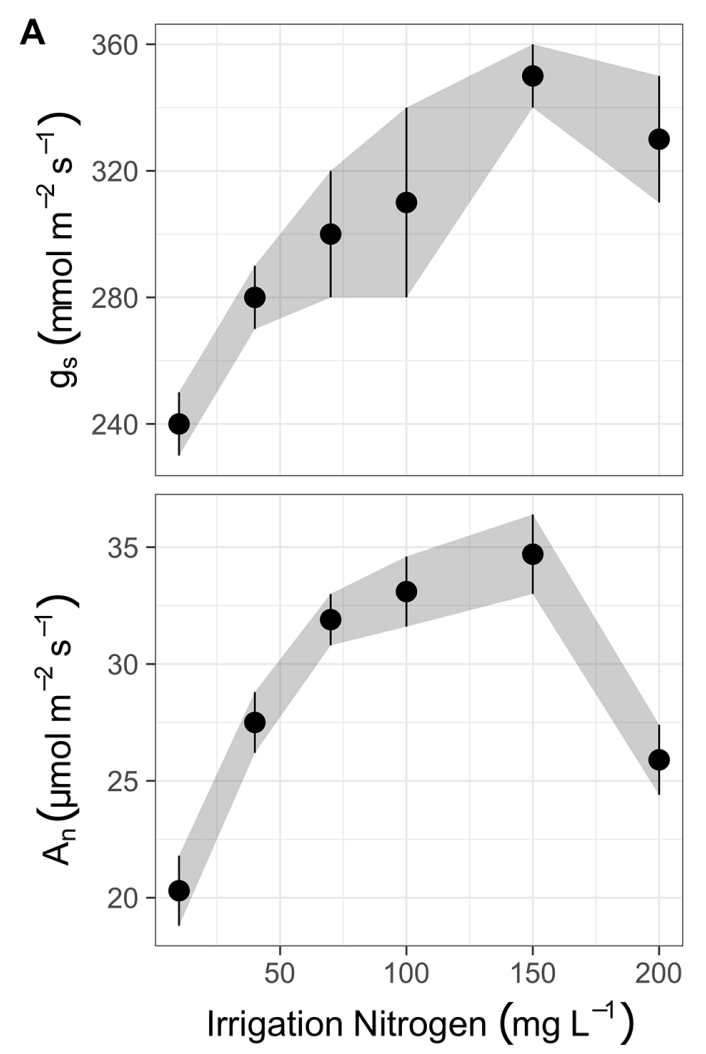

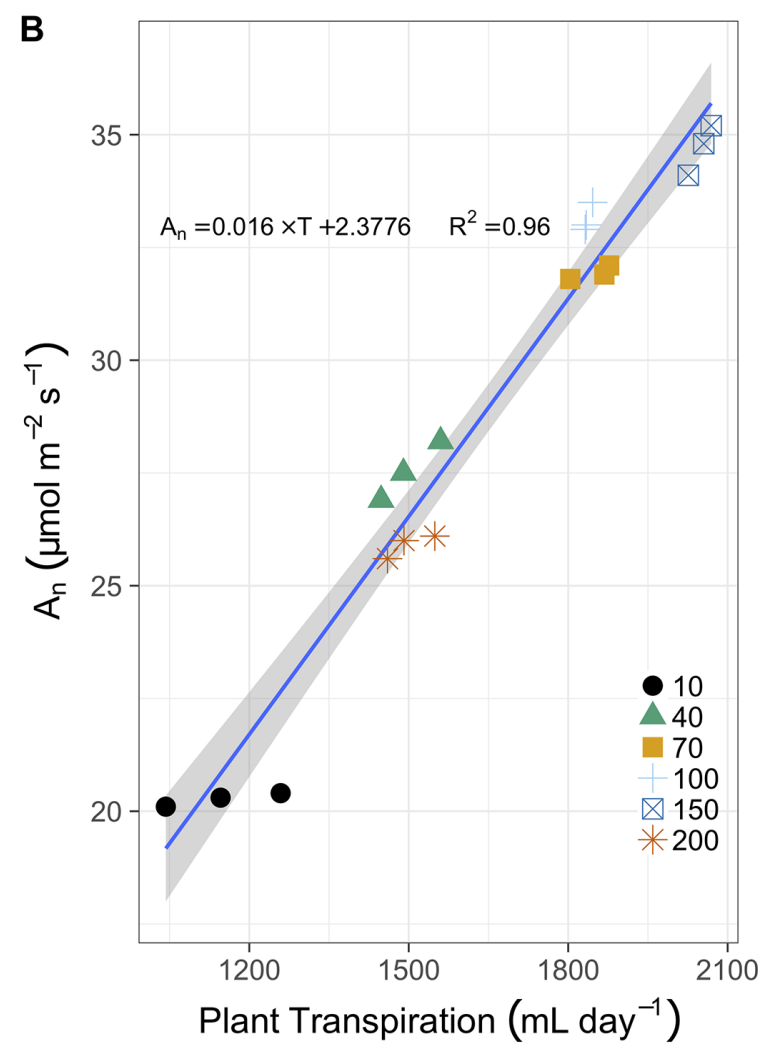

FIGURE 2 | (A) The response of stomatal conductance $\left(g_{s}\right.$, top panel, mmol m-2 $\left.\mathrm{s}^{-1}\right)$ and photosynthesis rate $\left(A_{n}\right.$, bottom panel, $\left.\mu m o l m^{-2} s^{-1}\right)$ after 100 days of $\mathrm{N}$ fertigation at concentrations from 10 to $200 \mathrm{mg} \mathrm{L}^{-1}$ (means of 3 biological replicates $\pm \mathrm{SE}$ ). (B) The correlation between photosynthesis and cumulative daily transpiration ( $\mathrm{ml} \mathrm{day}^{-1}$ ) for $\mathrm{N}$ concentrations from 10 to $200 \mathrm{mg} \mathrm{L}^{-1}$ (represented by various shapes and colors in legend), the linear regression (blue line and text for equation), and the 95\% confidence intervals (grey ribbon).

this resembled the trend of root mass accumulation. In fact, both SC and starch levels were linearly correlated to cassava root production, independent of $\mathrm{N}$ irrigation levels (Figure 3B). Yields averaged $311 \mathrm{~g} \mathrm{plant}^{-1}$ in plants irrigated with $10 \mathrm{mg} \mathrm{N}$ $\mathrm{L}^{-1}$, with $28 \mathrm{~g} \mathrm{mg}^{-1} \mathrm{SC}$ and $50 \mathrm{mg} \mathrm{g}^{-1}$ starch, and doubled to $616 \mathrm{~g}$ plant $^{-1}$ for plants irrigated with $150 \mathrm{mg} \mathrm{N} \mathrm{L}^{-1}$, which increased $\mathrm{SC}$ and starch to 50 and $72 \mathrm{mg} \mathrm{g}^{-1}$, respectively. Yet once more, the $200 \mathrm{mg} \mathrm{N} \mathrm{L}^{-1}$ treatment had negative effects on cassava plants as their leaves reduced SC to $40 \mathrm{mg} \mathrm{g}^{-1}$, starch was down to $65 \mathrm{mg} \mathrm{g}^{-1}$, and their yield dropped to an average of $393 \mathrm{~g} \mathrm{plant}^{-1}$ (a $36 \%$ yield loss).

\section{DISCUSSION}

With the increasing importance of cassava production and the prominent role fertigation plays in modern farming, we studied cassava's physiological responses to different irrigation $\mathrm{N}$ levels. Our research supports the notion that an excessive use of $\mathrm{N}$ would favor shoot vegetative growth and compromise yields. We were determined to assess whether cassava's nutritional status could be evaluated by the traditional $\mathrm{N}$ levels in diagnostic leaves and concluded that we need an alternative indicator of productivity for root crops. 

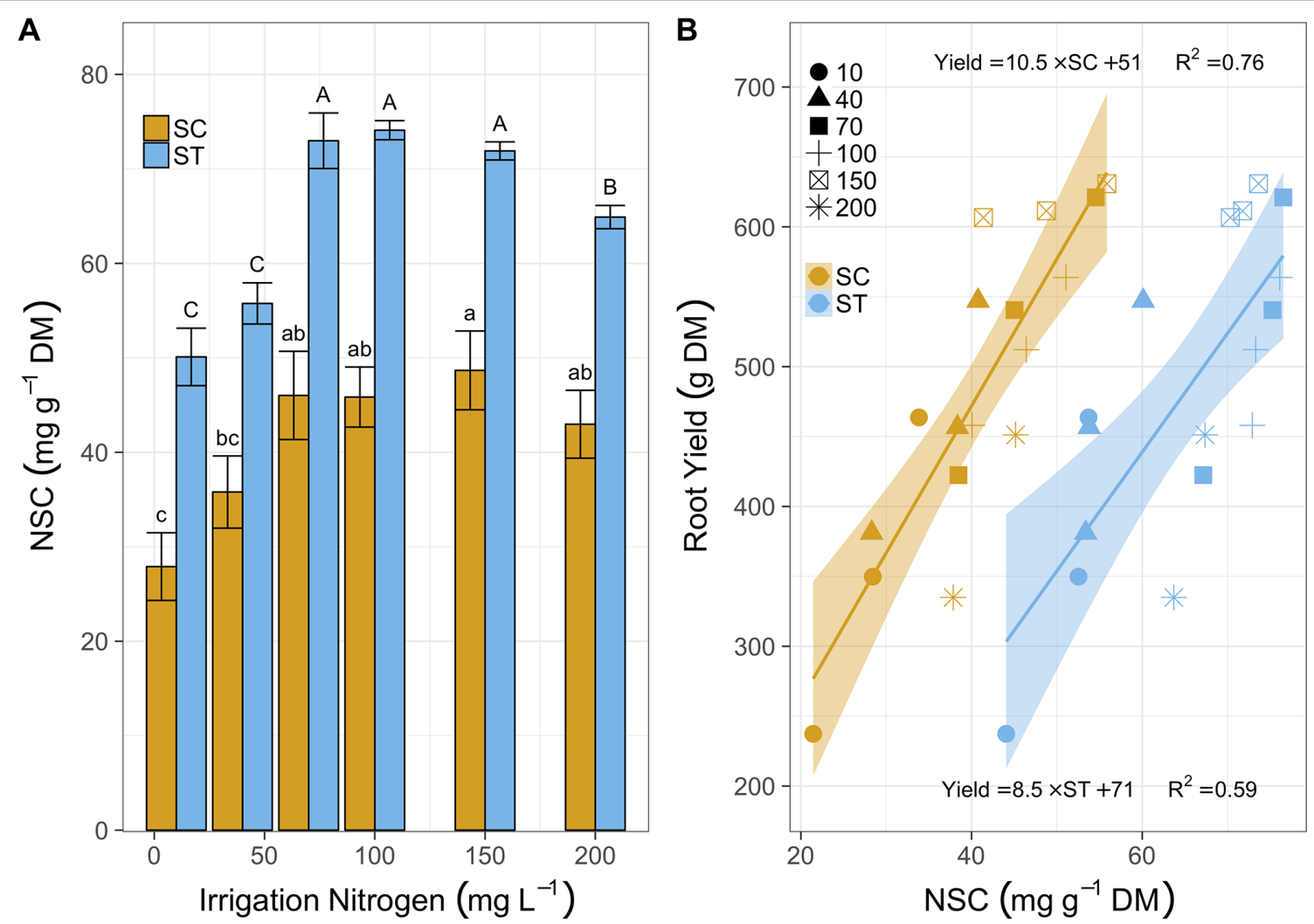

FIGURE 3 | (A) Soluble carbohydrates (SC, $\mathrm{mg} \mathrm{g}^{-1} \mathrm{DM}$, yellow bars) and starch (ST, blue bars) in leaves sampled after 81 days of treatment with irrigation $\mathrm{N}$ from 10 to $200 \mathrm{mg} \mathrm{L}^{-1}$. Bars represent means (3 biological replicates), error-bars denote SE, and letters stand for statistical differences (One-way ANOVA and Tukey-LSD, lowercase for SC and upper for starch, P < 0.05). (B) The relations between cassava root yield (g DM) and SC (yellow shapes) or starch (blue shapes) after 120 days of $\mathrm{N}$ fertigation ranging between 10 and $200 \mathrm{mg} \mathrm{L}^{-1}$ (various shapes). Lines (yellow for SC and blue for starch) illustrate positive linear regressions (equations and $\mathrm{R}^{2}$ are listed above line for SC and below the line for starch) and the ribbons mark the 95\% confidence intervals.

Nitrogen application increases cassava yields, but it might also promote shoot development over root growth and make $\mathbf{N}$ application ineffective. Nitrogen is arguably the biggest promotor of yields in modern farming (Spiertz, 2010), and it has shown the potential to increase cassava yields by $100 \%$. Yet, in low $\mathrm{N}$ availability (below $70 \mathrm{mg} \mathrm{L}^{-1}$ ), it led to contrasting effects. Additional $\mathrm{N}$ in such conditions, while probably stimulating canopy growth, photosynthesis, and NSC accumulation (Leuning et al., 1995; Millard and Grelet, 2010), did not translate to cassava root growth (and more yields for that matter). Apparently, carbon transport is limited in N-deficient cassava plants (Cruz et al., 2003a), which implies that root-crops might require substantial $\mathrm{N}$ application before fertilization pays off in increased yields. Higher N levels, between 70 and $150 \mathrm{mg} \mathrm{N} \mathrm{L}^{-1}$, were effective and increased cassava yields. At these $\mathrm{N}$ levels, plants benefit from acquiring more minerals, and therefore supply ample carbohydrates and recycled N to root growth (Thornley, 1972; Millard and Grelet, 2010), which is yield in cassava. Yet higher $\mathrm{N}$ concentrations, i.e., $200 \mathrm{mg} \mathrm{L}^{-1}$, underlined a most striking concern - excessive $\mathrm{N}$ can lower yields. In our research, the high $\mathrm{N}$ could lead to high levels of ammonium (due to nitrogen application in inert media with a fixed ammonium-nitrate ratio) and possible toxicity (Marschner and Marschner, 2012). Alternatively, high N levels could, somewhat counterintuitively, limit nitrate availability to roots, as it is probably assimilated in the shoot where nitrate reductase is most active (Cruz et al., 2004). Yet nearly similar limits to $\mathrm{N}$ fertigation in soil (70 to $\left.130 \mathrm{mg} \mathrm{L}^{-1}\right)$ were previously reported for an important tuber crop - potato (Papadoppoulos, 1988), with similar concerns at higher $\mathrm{N}$ levels, suggesting this is a broader phenomenon. Another explanation to why cassava yielded less, is that high $\mathrm{N}$ conditions could represent favorable growing conditions, trigger competition for light or space, and drive plants to promote vegetative development over root growth (Davis et al., 1999; Cruz et al., 2003a). In such a case, further fertigation is ineffective, monetarily wasteful, and environmentally concerning. Finally, cyanide is still a concern in some cassava cultivars (albeit not in the variety we studied) and it should be assessed in future studies because it is often attributed to high nitrogen availability (Burns et al., 2012). Yet none of these conditions could be recognized through the vitality of cassava growth, and therefore precise cassava $\mathrm{N}$ application calls for physiological indicators.

Traditional leaf mineral analyses fail to indicate whether cassava fertigation will promote yields (i.e., root growth) because total $\mathrm{N}$ in leaves hardly responds to changes in irrigation N. Generally, $\mathrm{N}$ concentration in leaves is not an optimal reference because it changes between species and throughout the growing season (Reich 
et al., 1991). Additionally, $\mathrm{N}$ uptake by mature leaves is negligible (Marschner and Marschner, 2012), and new $\mathrm{N}$ is primarily allocated through the transpiration stream to the younger leaves. In cassava, the growth rate is rather steady throughout the growing season (Keating et al., 1982), environmental water deficits and transpiration rate govern $\mathrm{N}$ deposition in the young, fully developed leaves (i.e., diagnostic leaves). Naturally, bigger plants and higher transpiration rates promote $\mathrm{N}$ accumulation in leaves. Yet high $\mathrm{N}$ availability will not necessarily promote soluble $\mathrm{N}$ accumulation in cassava leaves (Cruz et al., 2004), possibly because stunted plants (even due to $\mathrm{N}$ deficiency) grow less canopy and therefore accumulate $\mathrm{N}$ in their fewer, younger, leaves. Therefore, without extensive climatic, phenological, and variety-specific experiments, leaf mineral analyses are but arbitrary numbers and not a reference to precise farming. Nitrate in the petioles on the other hand, which represents the transient xylem sap solute composition (Wu et al., 2007), did denote the differences in the irrigation $\mathrm{N}$. Nevertheless, sap nitrate is also affected by the strength of $\mathrm{N}$ sinks (mainly new growth), and therefore it increases as plants grow, transpire more, and transport more residual $\mathrm{N}$ towards the premature leaves. Overall, it is difficult to determine $\mathrm{N}$ availability by its deposition without extensive empirical studies, but it is obvious that $\mathrm{N}$ uptake is tightly linked to transpiration and may affect its byproducts.

Nitrogen application affects cassava plants' assimilation and allocation of photosynthates. Low $\mathrm{N}$ availability biochemically limits carboxylation and photosynthesis of cassava plants (Cruz et al., 2003b). Accordingly, as irrigation $\mathrm{N}$ increased from 10 to $70 \mathrm{mg} \mathrm{L}^{-1}$, cassava plants supported more photosynthesis, which translated into increasing SC levels in the canopy. Yet starch did not increase $\left(53 \pm 4 \mathrm{mg} \mathrm{g}^{-1}\right)$, and that implies that these plants have not reached their photosynthetic capacity and that the canopy could not spare resources. Only when leaves reached a sugar threshold value of $47 \pm 4 \mathrm{mg} \mathrm{g}^{-1}$ did they begin to increase starch. They actually sustained peak starch levels of $73 \pm 2 \mathrm{mg} \mathrm{g}^{-1}$ for 70 ,
100 , and $150 \mathrm{mg} \mathrm{N} \mathrm{L}^{-1}$, which outlined the $\mathrm{N}$ treatments where fertigation was effective. As cassava is a starchy root crop, $\mathrm{N}$ at these levels promoted the allocation of these reserves to the roots (possibly by elevating ADP-glucose pyrophosphorylase activity (Ihemere et al., 2006) and improved yields. However, at $200 \mathrm{mg}$ $\mathrm{N} \mathrm{L}^{-1}$, a reduction in petiole nitrate demonstrated that these cassava plants could not fully support their canopy and needed to inhibit transpiration. Consequently, leaf stomatal conductance [supposedly not a limiting factor at low $\mathrm{N}$ conditions (Cruz et al., 2003b)], which linearly increased with irrigation levels so far, restricted water loss at $200 \mathrm{mg} \mathrm{N} \mathrm{L}^{-1}$ irrigation. Most importantly, this small change in conductance led to a dramatic drop in photosynthesis $(25 \%)$ and altered the carbohydrate availability to both roots and canopy. In fact, reduced root growth at fertigation of $200 \mathrm{mg} \mathrm{N} \mathrm{L}^{-1}$ could have suspended carbohydrates in the canopy and acted as feedback inhibitors to photosynthesis (Goldschmidt and Huber, 1992). Moreover, former reports suggest that SC could increase dramatically (despite no photosynthetic limitations) at only $90 \mathrm{mg} \mathrm{N} \mathrm{L}^{-1}$ (Cruz et al., 2003a). These shifts in carbohydrate status, easily, non-destructively, and inexpensively detectable at the leaf level, can actually disclose the cassava's nutritional status and indicate whether the fertigation is supporting yield. Moreover, these are physiological traits at the whole plant level that could be further studied in the field to produce an applied protocol and improve $\mathrm{N}$ application in cassava crops.

\section{CONCLUSIONS}

We identified three phases of cassava response to $\mathrm{N}$ fertigation that could be adjusted and extrapolated to other annual root crops (Figure 4). At low $\mathrm{N}$ levels, plant growth is strictly inhibited, and $\mathrm{N}$ addition dramatically enhances their photosynthesis, sugar levels, and aboveground vegetative growth. Yet the main energy investment at this phase is in the canopy, and root development (not yet a limiting

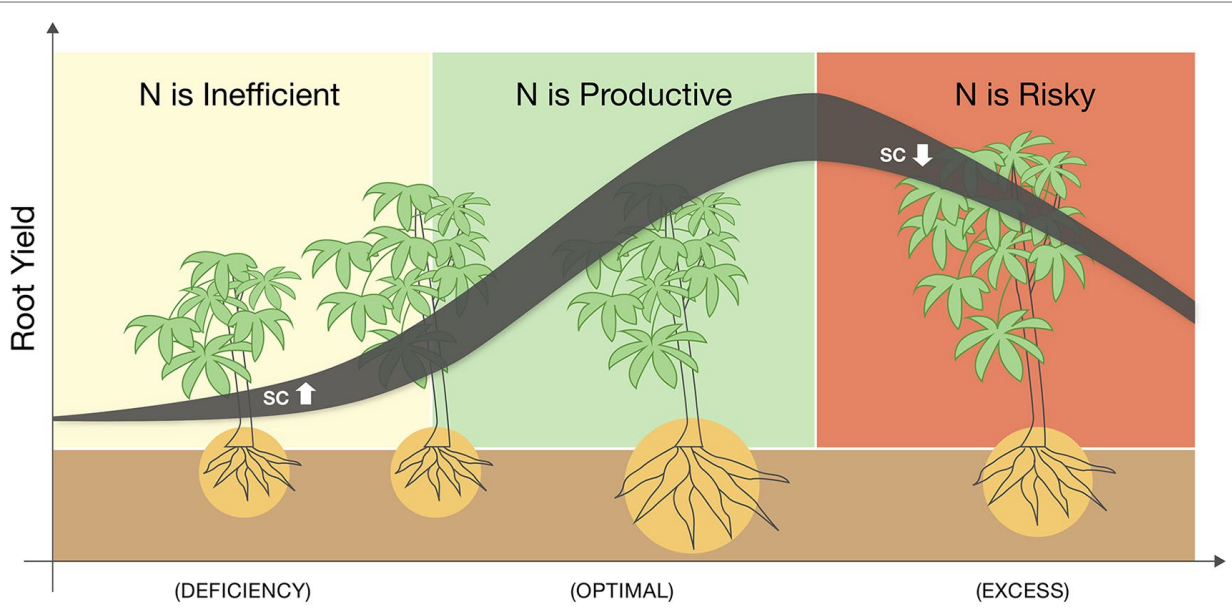

Nitrogen Level

FIGURE 4 | A schematic summary of a three-phase response of cassava to nitrogen fertigation ranging from deficient to excessive. Line denotes the yield response while its width represent changes in sugar (soluble carbohydrates, SC) levels in the leaves. Plant sizes illustrate the changes in roots vs. shoots biomass and the background colors mark were $\mathrm{N}$ application is infective (yellow), productive (green), or wasteful and risky (red). 
factor) is not promoted. For cassava (or any root-crop), $\mathrm{N}$ application in this range is potentially wasteful. At medium $\mathrm{N}$ levels, plants reach a threshold of vegetative growth and cellular sugar capacity and translocate resources (both $\mathrm{C}$ and $\mathrm{N}$ ) to the roots. Such roots develop faster and reciprocate with more water and nutrients to the demanding canopy. These are the conditions where $\mathrm{N}$ applications are highly effective. Yet at higher $\mathrm{N}$ levels the plant canopy becomes too demanding, and due to additional environmental constraints (e.g., irrigation regime, soil water capacity, or peak midday temperatures), roots fail to support it. In such conditions, plants become conservative, minimize water loss, photosynthesis, and carbohydrate redistribution. In this phase, farming inputs (both water and nutrients) exceed the plant's productive capacity, and further fertigation becomes an irresponsible practice that exhausts resources and risks the environment.

\section{DATA AVAILABILITY}

The datasets generated for this study are available on request to the corresponding author.

\section{REFERENCES}

Balagopalan, C. (2002). Cassava: biology, production and utilization. Hillocks RJ, Thresh JM, Bellotti AC, eds. Brasilia, Brazil: CAB. doi: 10.1079/9780851995243.0000

Bar-Tal, A., Aloni, B., Karni, L., and Rosenberg, R. (2001). Nitrogen nutrition of greenhouse pepper. II. Effects of nitrogen concentration and NO $3: \mathrm{NH} 4$ ratio on growth, transpiration, and nutrient uptake. HortScience 36, 1252-1259. doi: 10.21273/HORTSCI.36.7.1252

Burns, A. E., Gleadow, R. M., Zacarias, A. M., Cuambe, C. E., Miller, R. E., and Cavagnaro, T. R. (2012). Variations in the chemical composition of cassava (Manihot esculenta Crantz) leaves and roots as affected by Genotypic and Environmental Variation. J. Agric. Food Chem. 60, 4946-4956. doi: 10.1021/ jf 2047288

Byju, G., Nedunchezhiyan, M., Ravindran, C. S., Mithra, V. S. S., Ravi, V., and Naskar, S. K. (2012). Modeling the response of cassava to fertilizers: a site-specific nutrient management approach for greater tuberous root yield. Commun. Soil Sci. Plant Anal. 43, 1149-1162. doi: 10.1080/00103624.2012.662563

Cenpukdee, U., and Fukai, S. (1991). Effects of nitrogen supply on cassava/ pigeonpea intercropping with three contrasting cassava cultivars. Fertil. Res. 29, 275-280. doi: 10.1007/BF01052396

Cruz, J. L., Mosquim, P. R., Pelacani, C. R., Araujo, W. L., and DaMatta, F. M. (2003a). Carbon partitioning and assimilation as affected by nitrogen deficiency in cassava. Photosynthetica 41, 201-207. doi: 10.1023/B:P HOT.0000011952.77340.53

Cruz, J. L., Mosquim, P. R., Pelacani, C. R., Araújo, W. L., and DaMatta, F. M. (2003b). Photosynthesis impairment in cassava leaves in response to nitrogen deficiency. Plant Soil 257, 417-423. doi: 10.1023/A:1027353305250

Cruz, J. L., Mosquim, P. R., Pelacani, C. R., Araújo, W. L., and DaMatta, F. M. (2004). Effects of nitrate nutrition on nitrogen metabolism in cassava. Biol. Plant. 48, 67-72. doi: 10.1023/B:BIOP.0000024277.51293.02

Davis, M. A., Wrage, K. J., Reich, P. B., Tjoelker, M. G., Schaeffer, T., and Muermann, C. (1999). Survival, growth, and photosynthesis of tree seedlings competing with herbaceous vegetation along a multiple resource gradient. Plant Ecol. 145, 341-350. doi: 10.1023/A:1009802211896

El-Sharkawy, M. A. S., López, L. F. C., and de Tafur, M. S. M. (1998). Nutrient use efficiency of cassava differs with genotype architecture. Acta Agron. 48, 23-32. doi: $10.15446 /$ acag

Erel, R., Yermiyahu, U., Ben-Gal, A., Dag, A., Shapira, O., and Schwartz, A. (2015). Modification of non-stomatal limitation and photoprotection due to K and Na nutrition of olive trees. J. Plant Physiol. 177, 1-10. doi: 10.1016/j. jplph.2015.01.005

\section{AUTHOR CONTRIBUTIONS}

UY, NL, and SR conceptualized the research and guided the work, documentation, and analysis of the results. JOO set the experiments, conducted the field measurements, and documented the results. OS and UY guided the lab analysis and drafted the manuscript, while JOO, NL, SR, UY, and OS iteratively revised the manuscript until it was ready for submission.

\section{ACKNOWLEDGMENTS}

We thank the International Potash Institute and the African Development Bank for funding our work through the International Institute of Tropical Agriculture. The research was also funded by the Center for Fertilization and Plant Nutrition (CFPN; www.cfpn. center). We are also grateful to Meir Eliyahu for donating the plant materials and Ina Finegold, Yonatan Saroya, and Kristina Tabrizov who supported us in laboratory analysis, field installations, and data collection at Gilat Research Center, Agricultural Research Organization, Israel.

Fermont, A. M., Tittonell, P. A., Baguma, Y., Ntawuruhunga, P., and Giller, K. E. (2009). Towards understanding factors that govern fertilizer response in cassava: lessons from East Africa. Nutr. Cycl. Agroecosys. 86, 133-151. doi: 10.1007/s10705-009-9278-3

Goldschmidt, E. E., and Huber, S. C. (1992). Regulation of Photosynthesis by endproduct accumulation in leaves of plants storing starch, sucrose, and hexose sugars. Plant Physiol. 99, 1443-1448. doi: 10.1104/pp.99.4.1443

Grechi, I., Vivin, P., Hilbert, G., Milin, S., Robert, T., and Gaudillère, J.-P. (2007). Effect of light and nitrogen supply on internal C:N balance and control of rootto-shoot biomass allocation in grapevine. Environ. Exp. Bot. 59, 139-149. doi: 10.1016/j.envexpbot.2005.11.002

Gregoriou, K., Pontikis, K., and Vemmos, S. (2007). Effect of reduced irradiance on leaf morphology, photosyntetic capacity, and fruit yield in olive (Olea europaea L.). Photosynthetica 45, 172-181. doi: 10.1007/s11099-007-0029-x

He, L., Cao, T., Hu, X., Zhang, H., Zhang, X., Ni, L., et al. (2015). Effects of NH4+and $\mathrm{K}+$ enrichments on carbon and nitrogen metabolism, life history and asexual reproduction of Vallisneria natans L. in aquarium experiments. J. Freshw. Ecol. 30, 391-406. doi: 10.1080/02705060.2014.957740

Ihemere, U., Arias-Garzon, D., Lawrence, S., and Sayre, R. (2006). Genetic modification of cassava for enhanced starch production. Plant Biotechnol. J. 4 , 453-465. doi: 10.1111/j.1467-7652.2006.00195.x

Kang, J.-G., van Iersel, M. W., and Nemali, K. S. (2004). Fertilizer concentration and irrigation method affect growth and fruiting of ornamental pepper. J. Plant Nutr. 27, 867-884. doi: 10.1081/PLN-120030676

Kaweewong, J., Kongkeaw, T., Saowanuch, T., Sukunya, Y., and Russell, Y. (2013). Nitrogen requirements of cassava in selected soils of Thailand. J. Agr. Rural Dev. Trop. 114, 13-19.

Keating, B. A., Evenson, J. P., and Fukai, S. (1982). Environmental effects on growth and development of cassava (Manihot esculenta Crantz.) II. Crop growth rate and biomass yield. Field Crops Res. 5, 283-292. doi: 10.1016/0378-4290(82) 90031-4

Lassaletta, L., Billen, G., Grizzetti, B., Anglade, J., and Garnier, J. (2014). 50 Year trends in nitrogen use efficiency of world cropping systems: the relationship between yield and nitrogen input to cropland. Environ. Res. Lett. 9, 105011. doi: $10.1088 / 1748-9326 / 9 / 10 / 105011$

Lebot, V. (2008). "Cassava: origin and history," in Tropical root and tuber crops: cassava, sweet potato, yams and aroids. Eds. J. Atherton and A. Rees (Cambridge, USA: CABI), 3-12. doi: 10.1079/9781845934248.0003

Leuning, R., Kelliher, F. M., De Pury, D. G. G., and Schulze, E.-D. (1995). Leaf nitrogen, photosynthesis, conductance and transpiration: scaling from leaves to canopies. Plant Cell Environ. 18, 1183-1200. doi: 10.1111/j.1365-3040.1995. tb00628.x 
Leyva, A., Quintana, A., Sánchez, M., Rodríguez, E. N., Cremata, J. J., Sánchez, J. C., et al. (2008). Rapid and sensitive anthrone-sulfuric acid assay in microplate format to quantify carbohydrate in biopharmaceutical products: method development and validation. Biologicals 36, 134-141. doi: 10.1016/j.biologicals.2007.09.001

Li, Y., Ren, B., Ding, L., Shen, Q., Peng, S., and Guo, S. (2013). Does chloroplast size influence photosynthetic nitrogen use efficiency? PLoS One 8. doi: 10.1371/ journal.pone.0062036

Marschner, H., and Marschner, P. (2012). Marschner's mineral nutrition of higher plants. San Diego, USA: Academic Press.

Millard, P., and Grelet, G. A. (2010). Nitrogen storage and remobilization by trees: ecophysiological relevance in a changing world. Tree Physiol. 30, 1083-1095. doi: 10.1093/treephys/tpq042

Nassar, N. M. A. (2007). Wild and indigenous cassava, Manihot esculenta Crantz diversity: an untapped genetic resource. Genet. Resour. Crop Evol. 54, 1523-1530. doi: 10.1007/s10722-006-9144-y

Nguyen, H., Schoenau, J. J., Nguyen, D., Van Rees, K., and Boehm, M. (2002). Effects of long-term nitrogen, phosphorus, and potassium fertilization on cassava yield and plant nutrient composition in north vietnam. J. Plant Nutr. 25, 425-442. doi: 10.1081/PLN-120003374

Ospina, C. A., Lammerts van Bueren, E. T., Allefs, J. J. H. M., Engel, B., van der Putten, P. E. L., van der Linden, C. G., et al. (2014). Diversity of crop development traits and nitrogen use efficiency among potato cultivars grown under contrasting nitrogen regimes. Euphytica 199, 13-29. doi: 10.1007/ s10681-014-1203-4

Papadoppoulos, I. (1988). Nitrogen fertigation of trickle-irrigated potato. Fertil. Res. 16, 157-167. doi: 10.1007/BF01049771

Reich, P. B., Walters, M. B., and Ellsworth, D. S. (1991). Leaf age and season influence the relationships between leaf nitrogen, leaf mass per area and photosynthesis in maple and oak trees. Plant Cell Environ. 14, 251-259. doi: 10.1111/j.1365-3040.1991.tb01499.x

Sangakkara, U. R., and Wijesinghe, D. B. (2014). Nitrogen fertilizer affects growth, yield, and N recovery in cassava (Manihot esculenta L. Crantz). Commun. Soil Sci. Plant Anal. 45, 1446-1452. doi: 10.1080/00103624.2014.904330

SAS, I. Inc. (2002). SAS/STAT. SAS/STAT 9.2. Cary, NC, USA: SAS Institute Inc.

Sinclair, T. R., and Horie, T. (1989). Leaf nitrogen, photosynthesis, and crop radiation use efficiency: a review. Crop Sci. 29, 90. doi: 10.2135/cropsci1989.00 11183 X002900010023x
Snell, F. D., and Snell, C. T. (1949). Calorimetric methods analysis including some turbidimetic and nephelometric methods. Vol. 2. Inorganic. Toronto, Canada: Van Nostrand Inc.

Spiertz, J. H. J. (2010). Nitrogen, sustainable agriculture and food security. A review. Agron. Sustain. Dev. 30, 43-55. doi: 10.1051/agro:2008064

Susan John, K., Venugopal, V. K., and Saraswathi, P. (2007). Yield maximization in cassava through a systematic approach in fertilizer use. Commun. Soil Sci. Plant Anal. 38, 779-794. doi: 10.1080/00103620701220783

Thornley, J. H. M. (1972). A balanced quantitative model for root: shoot ratios in vegetative plants. Ann. Bot. 36, 431-441. doi: 10.1093/oxfordjournals.aob. a084602

Tonukari, N. J., Ezedom, T., Enuma, C. C., Sakpa, S. O., Avwioroko, O. J., Eraga, L., et al. (2015). White gold: cassava as an industrial base. Am. J. Plant Sci. 6, 972979. doi: 10.4236/ajps.2015.67103

Uwah, D. F., Effa, E. B., Ekpenyong, L. E., and Akpan, I. E. (2013). Cassava (Manihot esculenta Crantz) performance as influenced by nitrogen and potassium fertilizers in Uyo, Nigeria. J. Anim. Plant Sci. 23, 550-555.

Wu, J., Wang, D., Rosen, C. J., and Bauer, M. E. (2007). Comparison of petiole nitrate concentrations, SPAD chlorophyll readings, and QuickBird satellite imagery in detecting nitrogen status of potato canopies. Field Crops Res. 101, 96-103. doi: 10.1016/j.fcr.2006.09.014

Yermiyahu, U., Heuer, B., Silverman, D., Faingold, I., and Avraham, L. (2017) Nitrate analysis of Diplotaxis tenuifolia: fresh versus dry material for meeting international standards and regulations. Isr. J. Plant Sci. 9978, 1-4. doi: $10.1080 / 07929978.2017 .1288388$

Conflict of Interest Statement: The authors declare that the research was conducted in the absence of any commercial or financial relationships that could be construed as a potential conflict of interest.

Copyright (c) 2019 Omondi, Lazarovitch, Rachmilevitch, Yermiyahu and Sperling. This is an open-access article distributed under the terms of the Creative Commons Attribution License (CC BY). The use, distribution or reproduction in other forums is permitted, provided the original author(s) and the copyright owner(s) are credited and that the original publication in this journal is cited, in accordance with accepted academic practice. No use, distribution or reproduction is permitted which does not comply with these terms. 